\title{
O URBANISTA POR SEUS LIVROS: POSSÍVEIS LEITURAS SOBRE A BIBLIOTECA DE ANTÔNIO BALTAR
}

The Urbanist By His Books: Possibles Reedings Of Antônio Baltar's Library

\section{Virgínia Pontual}

Universidade Federal de Pernambuco

virginiapontual@gmail.com

\section{Renata Cabral}

Universidade Federal de Pernambuco

renatacabral@yahoo.com.br

\section{Juliana Melo Pereira}

Centro Universitário do Vale do Ipojuca

melo.arquiteta@gmail.com

\section{RESUMO}

O artigo discorre sobre as possibilidades de pesquisa geradas a partir da inventariação do acervo de livros que pertenceu ao urbanista Antônio Bezerra Baltar, autor de importantes contribuições como "Diretrizes de um Plano Regional para Recife" e "Índices Característicos do Desenvolvimento Urbano". Doado em 1998, à Universidade Federal de Pernambucoo acervo contém cerca de 2000 exemplares, em diversos idiomas e temáticas no campo da arquitetura, urbanismo, planejamento urbano e regional, sociologia, economia entre outros. Embora seja marcado pela dispersão em diferentes momentos, o acervo ainda constitui um importante conjunto documental passível de ser explorado não só pelos que buscam compreender a trajetória de Baltar, mas pelo mais diversos interesses elencados nas páginas seguintes.

\section{Palavras-chave}

Antônio Bezerra Baltar; Biblioteca; Urbanismo.

\section{ABSTRACT}

The article discusses the possibilities of research generated from the inventory of the collection of books that belonged to Antonio BezerraBaltar. Thisurbanistwasauthorofimportantcontributions as "Diretrizes de um Plano Regional para Recife" and"Índices Característicos do Desenvolvimento Urbano". The collection was donated in 1998, to the Federal University of Pernambuco, it contains approximately 2000 copies, whose are in multiple languages and topics in the field of 
architecture, urbanism, urban and regional planning, sociology, economics and others. It is characterized by dispersion at different times, but the collection still constitutes an important body of documents likely to be exploited by those who seek to understand the Baltar's trajectory, and the varied interests listed on the following pages.

\section{Keywords}

Antônio Bezerra Baltar; Library; Urbanism.

\section{INTRODUÇÃO}

Em 1998, um acervo com cerca de 2000 volumes da biblioteca pessoal de Antônio Bezerra Baltar- entre livros, periódicos e cadernos, em diversos idiomas - foi doado à Biblioteca Joaquim Cardozo, do Centro de Artes e Comunicação da Universidade Federal de Pernambuco (UFPE). Desde então, nunca houve uma catalogação que permitisse disponibilizar ao público a consulta do mesmo enquanto conjunto e como fonte para o estudo da trajetória profissional desse engenheiro. Cientes da importância deste urbanista, uma equipe multidisciplinar se propôs a realizar tal tarefaatravés da criação de um site, tornando essa catalogaçãoacessível ao público em geral. ${ }^{1}$

Este artigo foi apresentado no III Congresso Internacional de História Urbana e é consequência do esforço em definir chaves de sistematização e permitir que o inventário servisse aos mais diversos interesses de pesquisa. Nas páginas a seguir, são elencadas, primeiramente, as diversas possibilidades de pesquisa percebidas no contato com o acervo e, em seguida,estabelece-se uma relação deste com a trajetória do urbanista Antônio Baltar, ainda de forma preliminar, resultado, também, dessa primeira aproximação ao acervo referido.

\section{A BIBLIOTECA}

Com publicações em sete línguas e abrangendo campos disciplinares variados, como economia, arquitetura, engenharia, geografia, matemática, estatística, administração e sociologia, o acervo encontra-se hoje no setor de 'Coleções Especiais - Antônio Baltar'.O acervo doado constitui parte da biblioteca do urbanista, mas não é a sua totalidade. Livros e revistas de arquitetura, história da arte e alguns livros sobre

\footnotetext{
${ }^{1}$ Pesquisa "Antônio Bezerra Baltar: o acervo de um urbanista de vanguarda em Pernambuco" aprovada pelo Edital Funcultura 2012/2013 (Fundarpe-Governo do Estado de Pernambuco).Disponível em <http://www.ceci-br.org/acervobaltar/>.

URBANA, V.6, no 8, jun.2014 - Dossiê: Cidade e Habitação na América Latina - CIEC/UNICAMP
} 
planejamento urbano foram doados em 1965 à esposa de seu filho Luiz, a arquiteta Maria Teresa Moreira Baltar.

Dentre as revistas, pode-se destacar a Architecture d'aujourd'hui, da qual possuíatodos os números publicados no período de 1940 a 1964 . Essa coleção foi vitimada pela cheia de 1966. Os inúmeros exemplares da Revista do Patrimônio Histórico e Artístico Nacional, por sua vez, encontram-se até hoje em posse da família. $^{2}$

Quando Baltar saiu do Brasil para o exílio, em1965, sua biblioteca foi guardada pelo amigo e compadre Ayrton Carvalho, na sede do ${ }^{\circ}$ Distrito do Instituto do Patrimônio Histórico e Artístico Nacional, no Recife. Uma parte também foi abrigada no escritório doProfessor Maurício Coutinho ${ }^{3}$. Quando de seu retorno ao país, os livros foram transferidos para um pequeno apartamento onde funcionou o seu escritório, na Rua Manoel Borba, no Recife. Quando o escritório foi fechado, caixas desse acervo foram guardadas na sede da consultoria Acqua-plan, onde diversos cadernos de anotação de Baltar foram vitimados por cupim.

Na década de 1990, por sua vez, livros de matemática foram passados a uma neta, Paula Moreira BaltarBellemain.Além disso, periódicos do acervo foram levados pela filha Marieta para a Agência Estadual de Planejamento e Pesquisas de Pernambuco (CONDEPE/FIDEM), como aqueles de Economia e Humanismo.

Após os momentos citados de dispersão do acervo - o primeiro, no período de exílio, em que os livros ficaram em posse dos amigos Carvalho e Coutinho; o segundo, com o ataque de cupins àsede da Aqua-plan; e o terceiro, com doações a familiares e instituições - ainda restava uma considerável quantidade de livros e periódicos.

Cinco anos antes do falecimento de Baltar, este acervo restantefoi doado à Universidade, lugar muito caro ao docente, que revela, em depoimento feito em 1995, que sua maior vocação era ser professor(MONTENEGRO et ali, 1995:29-30).A escolha do lugar de destino de seus livros foi do próprio Baltar. Na memória da filha Letícia, ficou a imagem dela e do pai acompanhando em carro os livros sendo levados em um caminhão baú para o campus, trajeto marcado por uma emoção que se fez expressar em lágrimas. ${ }^{4}$

\footnotetext{
2 Entrevista com Luiz Baltar, filho do urbanista, realizada por e-mail em 10 nov. 2013.

3 Entrevista com quatro filhos de Baltar - Abelardo, Luiz, Letícia e João - em 9dez. 2013. Gravada. Duração de 1h30min. Os filhos não sabem precisar bem essa passagem pela sala do Prof. Maurício Coutinho.

${ }^{4}$ Ibidem.
} 
Nos últimos anos, a professora Virgínia Pontual tem se dedicado ao estudo desse acervo. Em 2009, foi feito um levantamento de 649 livros da biblioteca, que estavam disponíveis ao acervo de consulta, assim como a classificação desse universo bibliográfico, segundo ano e lugar de aquisição por Baltar e também por campo disciplinar. ${ }^{5}$ É importante ressaltar que a dispersão do acervo também aconteceu internamente à biblioteca Joaquim Cardozo, pois uma parte foi disponibilizada à consulta sem identificação especial, e até o momento de finalização deste trabalho, novos títulos pertencentes ao acervo estavam sendo descobertos e recolhidos para a 'Coleção Especial - Antônio Baltar'.

Anteriormente, foram realizados alguns trabalhos de pesquisa no curso deBiblioteconomia buscando a organização e processamento de parte do acervoBaltar, chegando à inserção de alguns títulos na base de dados da biblioteca. Nesse momento, os livros receberam uma numeração, um carimbofoi preenchido em caneta, com código de localização.Tal intervenção levou inicialmente à hipótese de ser uma sistematização do próprio Baltar, o que foi negado durante as entrevistas com a família, pois o registro de localização feito pelos pesquisadores não é contemporâneo ao carimbo. Esse foi feito pelos filhos de Baltar antes da saída do pai para o exílio, quando marcaram todos os exemplares do acervo (Figura 1).

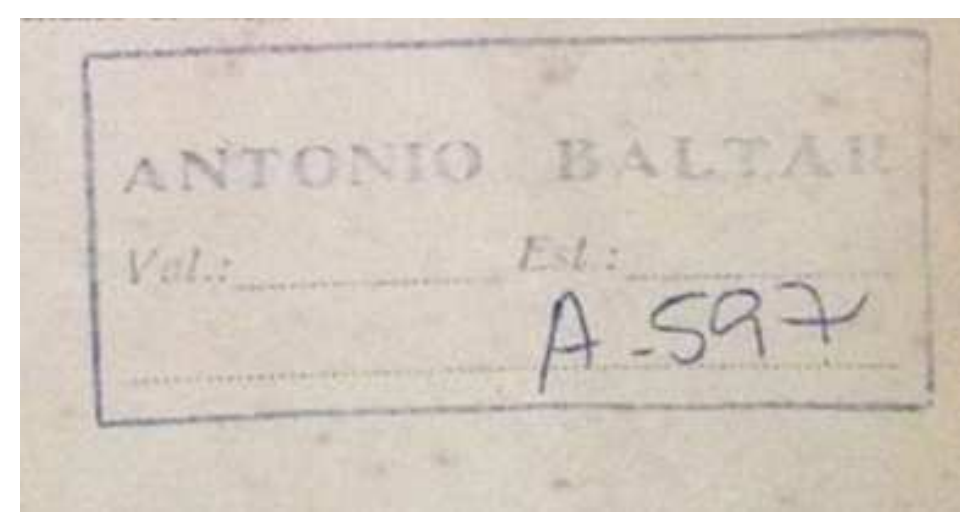

Figura 1: Carimbo de sistematização da biblioteca inserido pela família e intervenção posterior dos pesquisadores de biblioteconomia.

Fonte: Acervo da pesquisa.

Em 2013,o grupo de pesquisa da Prof.a VirgíniaPontual iniciou o trabalho de catalogação dabiblioteca, através do Edital Funcultura, promovido pela Fundação do Patrimônio Histórico e Artístico de Pernambuco.Na equipe multidisciplinar dialogaram

\footnotetext{
${ }^{5}$ Resultado do projeto de iniciação científica de Luiz Monte (2009).

URBANA, V.6, no 8, jun.2014 - Dossiê: Cidade e Habitação na América Latina - CIEC/UNICAMP
} 
profissionais da arquitetura, biblioteconomia e sistema de informações a fim de sistematizar edisponibilizara catalogação da biblioteca em website. ${ }^{6}$

Com todas as perdas supracitadas, abiblioteca de Baltarpossui reduzido número de obras em português em detrimento daquelas estrangeiras: espanhol, inglês, francês, italiano, alemão e sueco. Sabe-se que ele tinha fluência em inglês, francês e espanhol e conhecimentos básicos de alemão e italiano, que Ihe permitiam também ler nesses idiomas. O francês e inglês ele já dominava pelo menos desde a década de 1930.

Durante o desenvolvimentodo sistema de busca, foi decidido que as palavraschaves seriam mantidas em sua língua original. Essa escolha foi feita para respeitar a cultura dos países estrangeiros, expressa em sua língua, como é o caso, para dar apenas um exemplo, do importante significado que as palavras ediliziacittadina e stadtbäu possuem para a cultura urbanística italiana e alemã, respectivamente.

Pensando, ainda, nas possibilidades de pesquisa oferecidas por essa biblioteca, podemos fazer referência à condição de se construir um mapa de livrarias que desenha um certo circuito técnico-profissional de aquisição de livros. No acervo pesquisado, destaca-se, em Recife, a livraria Imperatriz, fundada em 1930 no bairro da Boa Vista; em São Paulo, as livrarias Kosmos, Triângulo (Figuras 2 e 3 ) e a Livraria Francesa. Selos e carimbos do Rio de Janeiro, Porto Alegre, Nova York, Londres, Santiago, Montreal, dentre outros ${ }^{7}$, também compõem essa trama de pontos comerciais de circulação de livros nacionais e estrangeiros comprados por ele ao longo de sua vida.
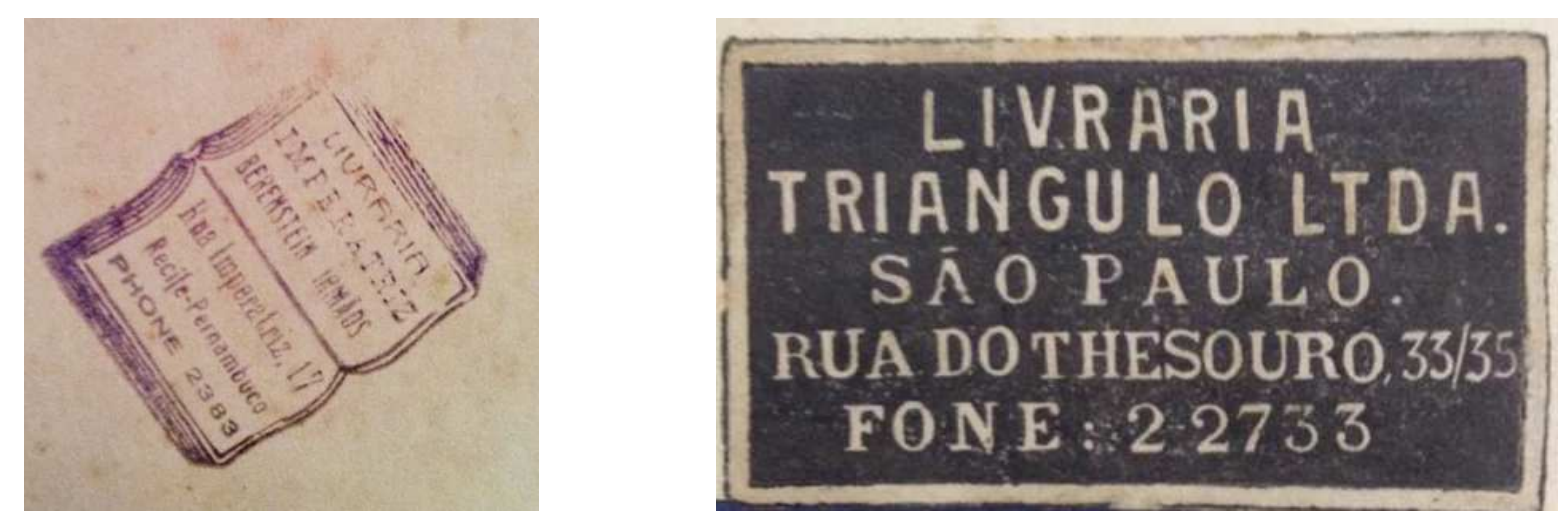

Figuras 2 e 3: Selos da livraria Imperatriz (Recife) e livraria Triângulo (São Paulo) Fonte: Acervo da pesquisa.

\footnotetext{
${ }^{6}$ Fizeram parte da equipe, além das autoras deste artigo: as arquitetas Isabella Trindade e Laura Alecrim, a biblioteconomistaSally Barbosa, o engenheiro de software Caio Neves e os estagiários, Bruno Fernandes, Jonh Sandoval e Pedro Lima.

${ }^{7}$ Interessante identificar a ausência de livros com selo da livraria paulista "Duas Cidades", muito frequentada pelos que compuseram o Movimento Economia e Humanismo no Brasil.
} 
É significativo o número de obras importadas adquiridas nas livrarias brasileiras. O hábito de Baltar assinar, datar e, por vezes, inserir o local de compra nos livros é mais um "presente" ao pesquisador (Figuras 4 e 5). Também chama a atenção a proximidade entre a data de aquisição por Baltar e a data de publicação, mostrando uma grande velocidade na circulação internacional dos livros e grande atualização de Baltar. Em grande parte das vezes, os livros foram adquiridos no ano seguinte ao da publicação.
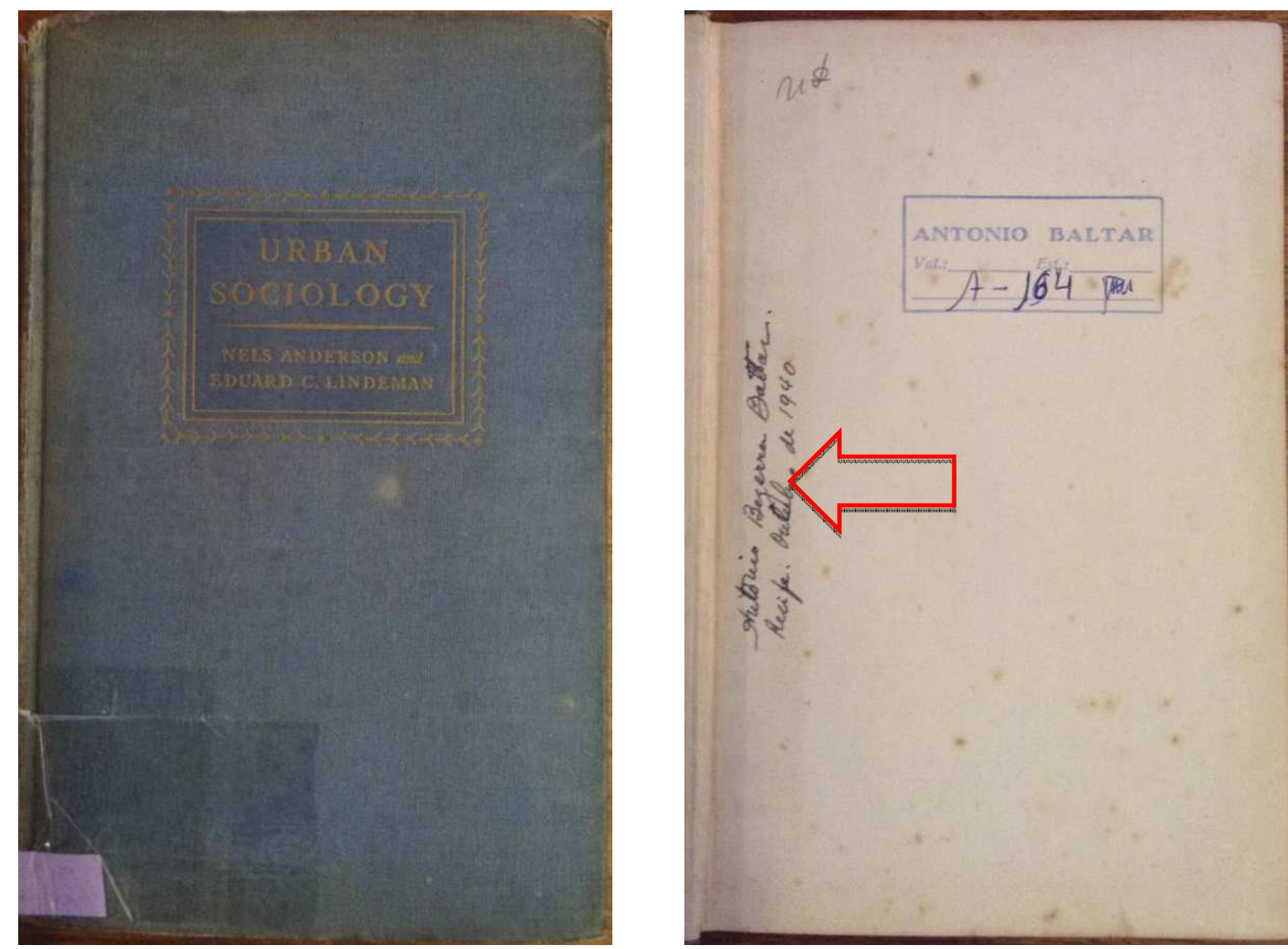

Figuras 4 e 5: Exemplar do livro Urban Sociology (ano de publicação 1935) com assinatura em destaque: "Antônio Bezerra Baltar. Recife. Outubro de 1940"

Fonte: Acervo da pesquisa.

A atualização constante de Baltar se assemelha a do engenheiro José Estelita, que, mesmo sem nunca ter saído do país, dispunha de um acervo invejável de livros recém publicados. É importante destacar que a proximidade de Estelita e Baltar, nos leva a levantar a hipótese que este também tenha sido um importante interlocutor nessa rede de compradores de livros de urbanismo e outros saberes.

Apesar de não haver clareza sobre como era o processo de aquisição de livros estrangeiros por Baltar, quando comprados nas livrarias brasileiras. Por outro lado, 
identificam-se, no acervo,livros estrangeiros sem carimbo de livrarias brasileiras. Algumas editoras estrangeiras tem grande participação no universo dos livros do engenheiro, levando-nos a pensar que Baltar acompanhou algumas delas de perto.

Segundo a lembrança do filho, Luiz Baltar, ${ }^{8}$ ao menos uma das editoras estrangeiras encaminhava automaticamente, por reembolso postal, todos os seus lançamentos de determinados autores e assuntos. Ele faz referência àMcGraw-Hill, especialmente na área de economia e estatística. Relata, ainda, que ele recebia também catálogos dessas editoras.

Aos que se dedicam ao estudo de trajetória ou da circulação de ideias, a biblioteca permite ver Baltar em redes intelectuais, profissionais ou pessoais, a partir das dedicatórias a ele feitas. Nas contracapas dos volumes, se revelam figuras como o geógrafo Mário Lacerda de Melo ou José Paulo Cavalcanti Filho, que se autointitulacompanheiro de futebol de Baltar em sua missiva(Figura 6).

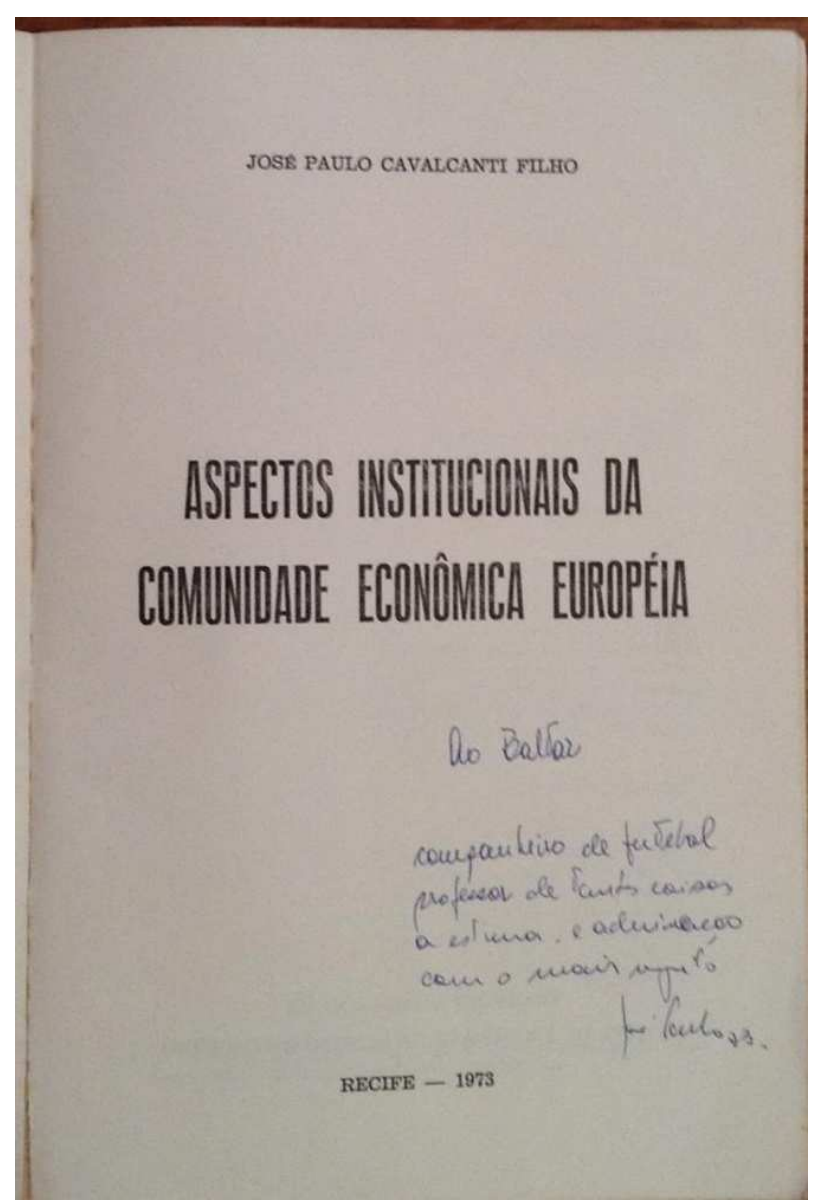

Figura 6: Dedicatória de José Paulo Cavalcanti Filho. "Ao Baltar, companheiro de futebol, professor de tantas coisas, a estima e admiração. com maior respeito, José Paulo, 73". Fonte: Acervo da pesquisa.

\footnotetext{
${ }^{8}$ Entrevista com Luiz Baltar, filho do urbanista, realizada por e-mail em $1^{\circ}$ nov. 2013.
} 
As redes de relações também aparecem a partir de livros assinados por outras pessoas e que foram compor a biblioteca de Baltar, como exemplares do engenheiro Joaquim Cardozo, professor de Baltar na Escola Livre de Engenharia e colaborador da Diretoria de Arquitetura e Urbanismo, onde o mesmo estagiou. Ou, ainda, exemplares do genro e político Roberto Freire e do jovem amigo Sérgio Buarque.

Segundo depoimento de Luiz Baltar, Sérgio Buarque estava em Santiago do Chile em setembro de 1973, quando ocorre o golpe militar deste país. Perseguido, deixou às pressas o apartamento onde morava, e Baltar o abrigou com a família em sua casa. Após alguns dias, Baltar teria levado Sérgio e família para a embaixada, de onde saíram para o exílio na Europa. Posteriormente, funcionários das Nações Unidas recolheram o que restou dos pertences da família Buarque e, por determinação do próprio Sérgio, entregaram os seus livros a Baltar. Quando voltou ao Brasil, Baltar trouxe a caixa de livros e entregou a Buarque em Recife e nessa operação podem ter se misturado livros dos dois 9 .

Foram encontrados, ainda, livros com assinatura de posse de "E. Wanderley" e "Magalhães". Os filhos de Baltar identificaram ${ }^{10} \mathrm{o}$ primeiro como sendo o professor Eduardo Wanderley, chefe de clínica cirúrgica na Faculdade de Medicina da Universidade do Recife, onde Baltar contribuía com aulas de estatística médica. O livro de Wanderley que permanece no acervo de Antônio Baltar é justamente sobre Introduction to Medical Biometry and Statistics.

Uma outra possibilidade gerada através dos livros de Baltar é ajudar a entender o processo de leitura e construção do conhecimento por ele. Apesar de poucos, são muito ricos os livros que apresentam marginália. Ainda segundo relato de seu filho Luiz, Baltar fazia anotações em cadernos e muitas dessas anotações aproveitava como notas de aula. Alguns dos cadernos de anotações, remanescentes do períodono qual ele fechou o escritório que tinha na Rua Manoel Borba, foram guardados em caixas destruídas na sede Acqua-plan, como anotado anteriormente.Encontram-se, contudo, alguns cadernos no acervo da biblioteca Joaquim Cardozo.

Um dos livros com marginália é o Géographie des Villes, de Pierre Lavedan (1936). Nele,a leitura de Baltar é voltada à comparação com a realidade pernambucana, mostrando uma erudição que vai se construindo a partir de um olhar interessado, sobretudo, na sua realidade geográfica, social e política (Figura 7).

\footnotetext{
${ }^{9}$ Ibidem.

10 Entrevista com quatro filhos de Baltar - Abelardo, Luiz, Letícia e João - em 9dez. 2013. Gravada. Duração de 1 h30min.
}

URBANA, V.6, no 8, jun.2014 - Dossiê: Cidade e Habitação na América Latina - CIEC/UNICAMP 


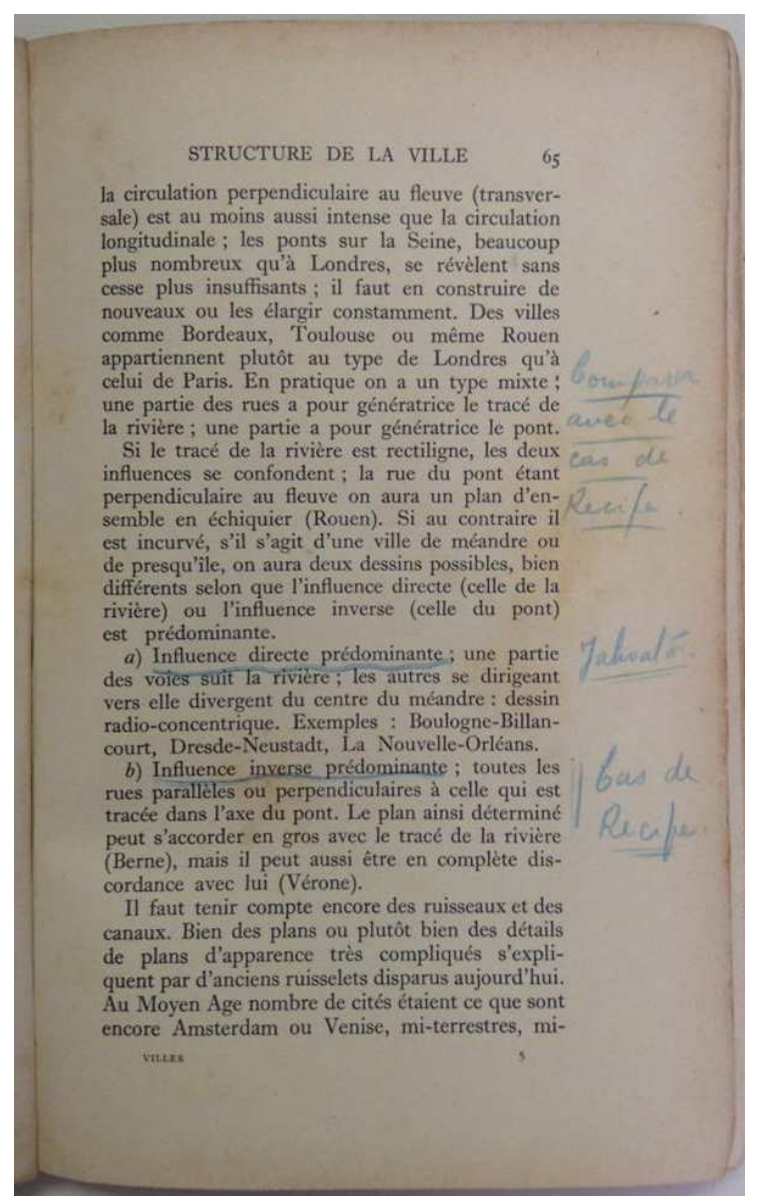

Figura 7: Página do livro Géographiedes Villes com grifos e anotações de Baltar:

"Compareraveclecas de Recife (...) Jaboatão (...) Cas de Recife"

Fonte: Acervo da pesquisa.

Em seu estudo sobre as marginálias de Mário de Andrade, Lopez (2013:66) mostra como "trabalhar com uma biblioteca desse tipo nos torna leitores de um singular leitor, de cujas marcas saem multiplicadas interrogações".

O acervo de livros também pode ser muito útil para uma análise intertextual dos escritos de Baltar, muitos deles presentes na biblioteca. Podemos, tendo em mãos os livros referenciados nos textos desse engenheiro, identificar como ele os utiliza, como os traduz (ou trai), colocando também como questão o papel que esses livros ocupam na narrativa.

Ao final da vasta bibliografia de aproximadamente 300 títulos da tese "Diretriz de um Plano Regional para o Recife", apresentada para o concurso à cátedra de Urbanismo e Arquitetura Paisagística na Escola de Belas Artes da Universidade do Recife em 1951, Baltar destaca a ausência de inúmeros trabalhos monográficos de urbanistas brasileiros por não terem sido "compulsados no período de organização" da tese, pois teriam sido lidos em época anterior e em exemplares que ele não possuiria em sua "estante". 
Esse depoimento, além de revelar a necessidade de explicitar uma delicada ausência, mostra a importância dessa "estante", sua biblioteca pessoal, na escrita desse trabalho.

Se, por um lado, a biblioteca serve a todas essas correlações explicitadas anteriormente, muitas das quais vão da biblioteca ao contexto,ela também deve ser vista comoobjeto em sua singularidade própria de conjunto. Alguns dos exemplares de Baltar estavam até a pouco, como foi citado, dispostos à consulta comum em meio aos demais livros, como acontece, similarmente, com o acervo de Anhaia Mello e o da Sociedade de Análises Gráficas e Mecanográficas Aplicadas aos Complexos Sociais (Sagmacs) na biblioteca da FAU-Pós Graduação ${ }^{11}$. Hoje, o entendimento na biblioteca Joaquim Cardozo é de que os livros de Baltar devem permanecer enquanto parte da coleção do engenheiro, visto em sua unidade (embora sem a integridade original) e historicidade.

Ao discutir a importância de acervos privados como o de Baltar, Santos (1999) menciona a importância do conjunto documental, pois apesar de cada peça ter valor único, perdem seu sentido quando isoladas. A autora ainda alerta para o mal que causa à integridade do acervo, a sua dispersão, cujos danos para seu valor histórico científico e cultural são irreparáveis.

No caso do acervo de Baltar, foi fundamental entrevistar a família para entender e registrar o estado de incompletude do acervo doado.As entrevistas ajudaram a entender o intrigante pequeno percentual de livros de arquitetura no acervo, a partir do relato de que grande parte desses livros foram doados a uma nora arquiteta, como referido anteriormente, assim como o pequeno número de periódicos.

No relato do filho,ainda aparece a biblioteca enquanto memória de unidade espacial e organizacional, hoje não mais existente:

Eram duas salas bastante grandes que somavam algo como $60 \mathrm{~m}^{2}$, com um birô $[. .$.$] , uma grande mesa, cheia de livros e de papeis, duas pranchetas e$ estantes de piso a teto, em todas as paredes, algumas prateleiras com duas camadas de livros.

À primeira vista era uma bagunça total, mas ele sabia onde estava cada livro. Uma única pessoa (Sr. Sílvio, antigo funcionário da Associação Brasileira de Cimento Portland) tinha autorização para, periodicamente, nos finais de semana, fazer uma limpeza nos livros [...]. Além dos livros de urbanismo, economia, estatística, matemática, engenharia rodoviária, tinha vários outros sobre sociologia, filosofia, música, pintura, etc, esses às vezes nas camadas dos fundos das estantes. Lembro que em determinada ocasião desejei ler algo sobre o jogo de xadrez. De onde estava no terraço de casa, ele me indicou:

\footnotetext{
${ }^{11}$ Notícia do Prof. Carlos Roberto Monteiro de Andrade (IAU-USP).

URBANA, V.6, n 8, jun.2014 - Dossiê: Cidade e Habitação na América Latina - CIEC/UNICAMP
} 
na estante tal, atrás do livro qual tem dois ou três livros sobre xadrez. Estavam lá (BALTAR, 2013).

Mesmo não sendo totalmente íntegra, com dispersão dos livros sobretudo de arquitetura e matemática, essa biblioteca condensa e pode assim ajudar a iluminar uma trajetória profissional vasta e variada. Ao discutir este tipo de acervo, Santos (1999) destaca o fato de ser conformado pelo próprio titular e expressar o vínculo pessoal que este tem com o mundo e acrescenta que "guarda a memória de seu titular e de seu tempo para as gerações futuras".

\section{O PROFISSIONAL}

O engenheiro Antônio Bezerra Baltar nasceu na cidade do Recife, no ano de 1915, integrante de família de classe média católica. Os seus primeiros estudos foram realizados em colégios católicos de prestígio local, como o Instituto Nossa Senhora do Carmo e o Colégio Nóbrega (pertencente à ordem dos jesuítas). Em 1932, aos dezessete anos de idade, Baltar ingressou na Escola Livre de Engenharia da Universidade do Recife, concluindo o curso em 1938 (MONTENEGRO et ali, 1995: 2930).

Com quase 50 anos de fundação, o curso de Engenharia no Recife já era referenciado regionalmente por sua excelência e contava com professores renomados como Joaquim Cardozo, Newton Maia, João Holmes Sobrinho, Luís Freyre, José Estelita, entre outros. Segundo Baltar, o ensino das matérias básicas era no nível das melhores universidades do mundo, ao ponto de alunos formados ingressarem sem dificuldade em instituições internacionais. Em relação ao ensino aplicado, a Escola não contava com o mesmo avanço, o que se deve ao atraso geral em que se encontravam os serviços públicos e empreendimentos de engenharia no país (MONTENEGRO et ali, 1995: 29- 30).

Em 1934, Baltar foi também admitido no curso de Arquitetura da Escola de Belas Artes de Pernambuco, mas não o concluiu por impedimentos de ordem normativa: não era permitido por legislação do Governo Federal um aluno fazer dois cursos superiores na mesma universidade simultaneamente.

Uma alternativa do estudante para suprir a carência da prática nos estudos foi o estágio na Diretoria de Arquitetura e Urbanismo (DAU), órgão da Secretaria de Viação e Obras do Estado de Pernambuco, então sob a coordenação do arquiteto Luiz Nunes $^{12}$. Fizeram parte desta equipe os engenheiros José Noberto, Gauss Estelita e

\footnotetext{
12 Luiz Carlos Nunes de Souza (1908-1937) formou-se arquiteto na ENBA, em 1931. Em 1934, foi convidado e contratado pelo governo de Carlos de Lima Cavalcanti para trabalhar na criação de espaços URBANA, V.6, nº 8, jun.2014 - Dossiê: Cidade e Habitação na América Latina - CIEC/UNICAMP
} 
Jaime Coutinho, o desenhista Hélio Feijó, os arquitetos cariocas Fernando Saturnino de Britto, João Corrêia Lima, o paisagista Roberto Burle Marx e o companheiro de Baltar nos estudos de engenharia, Ayrton Carvalho. O engenheiro Joaquim Cardozo colaborou constantemente com o grupo e, segundo Baltar, "exerceu uma impagável influência no progresso cultural de toda equipe - a ela não escapando sem dúvidas, o próprio Luiz Nunes" (BALTAR, in: XAVIER, 2003:357).

De acordo com Baltar, pela primeira vez no serviço público de Pernambuco houve uma tentativa de padronização, de materiais, expedientes, e construção, foram instituídos entre os técnicos a produção de relatórios diários de serviços, controladas as despesas. Além disso, as reuniões periódicas para discutir os problemas de cada obra despertavam o espírito de equipe. O ambiente de aprendizado sobre arquitetura e urbanismo, mediante contato com revistas técnicas internacionais e trocas de opiniões com os que faziam a DAU, marcaram os primeiros anos de sua formação.

Poucos são os livros na biblioteca datados desse período de formação. No entanto, surpreendemo-nos ao encontrar um caderno de anotações de Baltar datado de 1936, contendo uma tradução do capítulo IX de livro sobre termodinâmica (Thermodynamique: a l'usage dês ingénieurs), de Aimé Joseph Witz (Figura 8).

arquitetônicos destinados às instituições governamentais, realizou dezenas de projetos de arquitetura moderna em Pernambuco, entre os quais se destacam: a Caixa d'água de Olinda, o Pavilhão de Óbitos (atual sede do IAB), o Leprosário da Mirueira, etc. Faleceu precocemente em 1937, levando à dissolução da Diretoria. 


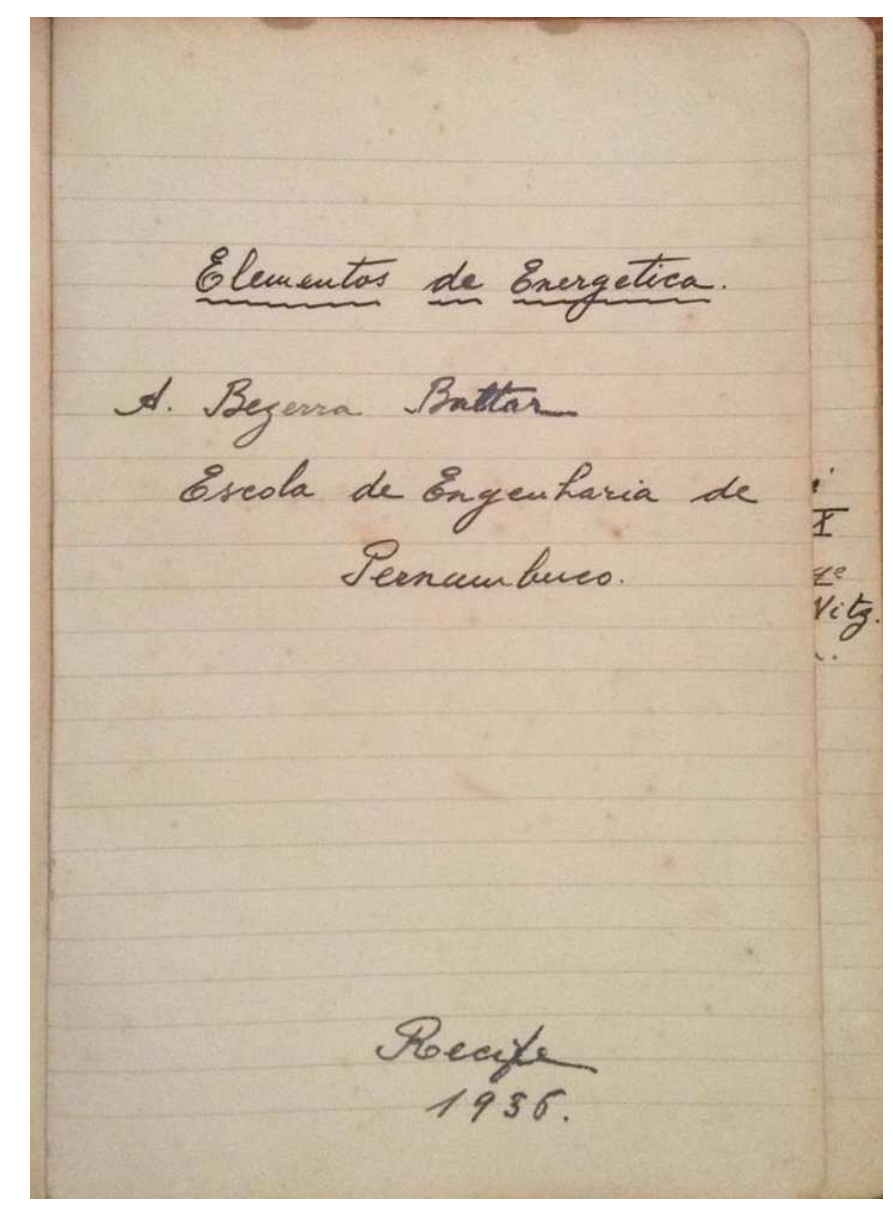

Figura 8: Caderno de anotações de Baltar (1936).

Fonte: Acervo da pesquisa.

Livros com assinatura e local de aquisição por Baltar no triênio posterior à sua graduação também são em número reduzido e mostram o interesse do jovem engenheiro em assuntos como arquitetura, matemática financeira, economia, sociologia urbana, geografia, em idiomas variados, como o italiano, o inglês, o alemão e o espanhol.

A trajetória de Baltar como engenheiro em organismos técnicos compreende passagens por diversas instituições desde sua conclusão do curso de engenharia até os anos de 1960: chefe do Departamento de Engenharia do Instituto da Previdência do Estado (Ipsep), engenheiro da Associação Brasileira de Cimento Portland (ABCP); Chefe de Distrito do Departamento Nacional de Estradas e Rodagens (DER); Diretor Superintendente da Companhia de Borracha Sintética (Coperbo).

Deste período, encontra-se em sua biblioteca o caderno de anotações como técnico do Ipsep, onde ingressou logo que se formou. No caderno, Baltar trata do processo de licitação da construção do prédio da Secretaria da Fazenda e Instituto de Previdência, exemplar da arquitetura moderna construído no Recife na década de 
1930, projeto em que trabalhou junto a Ayrton Carvalho e Fernando Saturnino de Britto, ex-colegas de trabalho do engenheiro na DAU.

Frente às transformações que ocorrem no Recife, entre as décadas de 1930 e 1950, especialmente com a reformas das áreas centrais à custo de grandes demolições, verticalização e abertura de novas avenidas como a 10 de Novembro (atual Guararapes) e Dantas Barreto, foi criada a Comissão do Plano da Cidade $(\mathrm{CPC})^{13}$. Na qualidade de urbanista, Baltar integra esta comissão em 1941, representando o Clube de Engenharia, para juntamente com representantes de diferentes instituições, acompanhar os planos e reformas urbanísticas na cidade. As Atas das reuniões da CPC revelam o destaque da atuação do engenheiro em várias proposições e deliberações acerca de problemas da cidade.

Também em 1941, Baltar passa a ministrar a disciplina de Urbanismo e Arquitetura Paisagística na Escola de Belas Artes, em substituição ao professor e engenheiro José Estelita. Ao precisar se ausentar por dois anos desta escola, Estelita indicou Baltar como substituto, pois já conhecia seu interesse por urbanismo desde a Escola de Engenharia, além de ter sido companheiro na CPC. Encerrada a licença do professor titular, Baltar teve que abandonar a cadeira, contudo devido à sua competência para o ensino, foi convocado e assumiu a disciplina de Perspectiva (MONTENEGRO et ali, 1995: 13). Outras oportunidades permitiram que Baltar ensinasse ainda as disciplinas de Pequenas Composições e Teoria da Arquitetura. A experiência com economia e estatística no Ipsep rendeu a Baltar também o convite a assumir a cadeira de Economia e Finanças, na Escola de Engenharia, em 1944, aulas de Estatística, na Faculdade de Medicina.

Muitos dos livros de arquitetura que continuaram no acervo são datados ainda da década de 1940, indício do reflexo da passagem de Baltar pelo DAU e pelo curso de arquitetura (Figuras 9 e 10).

\footnotetext{
${ }^{13}$ A primeira Comissão Consultiva do Plano da Cidade foi criada em 1931, pelo prefeito Lauro Borba, e dissolvida em 1935; nos anos de 1937 e 1938, houve duas tentativas sem sucesso de reativá-la; até que, em 1942, foi reativada pelo prefeito Antônio Novaes Filho, funcionou até 1952, quando foi substituída pela Comissão de Estudos e Planejamento do Recife, com outras atribuições (PONTUAL, 1998).
} 

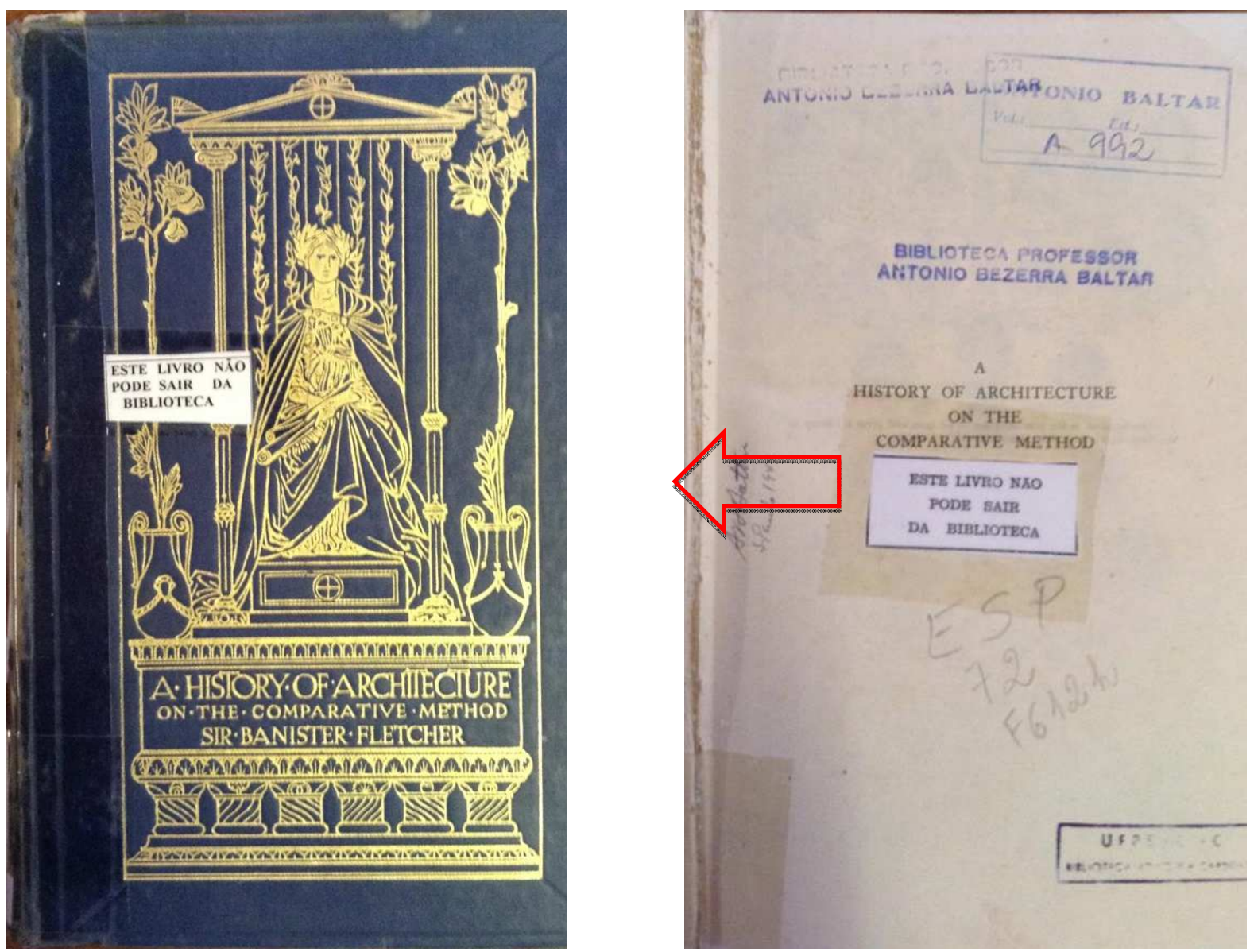

Figura 9 e 10: Exemplar do livro A history of architecture on the comparative method, assinatura: "Antônio Baltar. São Paulo, 1949".

Fonte: Acervo da pesquisa

Posteriormente, tornou-se professor auxiliar de Urbanismo, pois José Estelita se encontrava muito doente e não tinha condições de lecionar sozinho. Em 1951, Baltar prestou concurso para professor catedrático para a disciplina na escola em que já ensinava e foi aprovado. ${ }^{14} \mathrm{Na}$ ocasião, o engenheiro apresentou para a banca examinadora a já referida tese 'Diretrizes de um plano regional para o Recife', que não só the rendeu a aprovação, como foi também publicada no ano seguinte e considerada a obra mais reconhecida da trajetória de seu autor.

Além do "Diretrizes...", o conjunto da produção literária de Baltar, outras duas obras se destacam por sintetizarem as concepções urbanísticas do autor e constituem referências nos estudos realizados. São elas: "Índices Característicos do Desenvolvimento Urbano: tentativa de sistematização de uma teoria da urbanização das unidades residenciais" e "Seis Conferências de Introdução ao Planejamento Urbano", a serem tratados a seguir.

\footnotetext{
${ }^{14}$ Relatório de atividades da Escola de Belas Artes da Universidade do Recife, 1958-59.
} 
Na década de 1950, a predominância do assunto dos livros comprados é sobre Planejamento Urbano e regional. Em sua iniciação científica, Luiz Monte (2009) concluiu, ao relacionar quantidade de livros assinados por Baltar e o ano de aquisição, que o período que compreende a década de 1950 foi o de mais intensiva busca por leitura e conhecimento.

As reflexões iniciadas com 'Diretrizes...' foram apenas o ponto de partida para as pesquisas de Baltar, o instinto investigativo do engenheiro, juntamente com seus conhecimentos de estatística, matemática e economia o levaram a questões mais complexas do planejamento urbano, especialmente relacionada ao seu instrumental e indicadores que orientassem a prática neste campo (MONTE, 2009).

Frente a tal inquietação, Baltar desenvolveu uma teoria que atendeu aos seus anseios, e acabou servindo de base para pesquisas e planos de vários profissionais urbanistas. O trabalho denominado "Índices Característicos do Desenvolvimento Urbano: tentativa de sistematização de uma teoria da urbanização das unidades residenciais" foi apresentado em 1952 e publicado em 1958. Nesta obra, o engenheiro expõe sua convergência com as ideias do Movimento Economia e Humanismo, ao defender que crescimento é diferente de desenvolvimento, concluindo que este último não é limitado às condições materiais.

Ao construir sua teoria, Baltar conceitua o fenômeno de crescimento das cidades e demostra vasto conhecimento em estatística e matemática ao sistematizar, inclusive citando vários artigos. A relação entre duas grandezas básicas - população e área urbana - é trabalhada pelo engenheiro, que se mostra atualizado sobre as discussões do tema ao citar as ideias de diferentes autores como: Malthus, QueteletVerhulst, Pearl e Reed, Palmer Puthnam. Desses autores, ou sobre eles, encontramos, o Medical BiometryandStatistics, de Pearl, de 1940, e o livro Beyond Malthus, de Neil W. Chamberlain (Figura 11). 

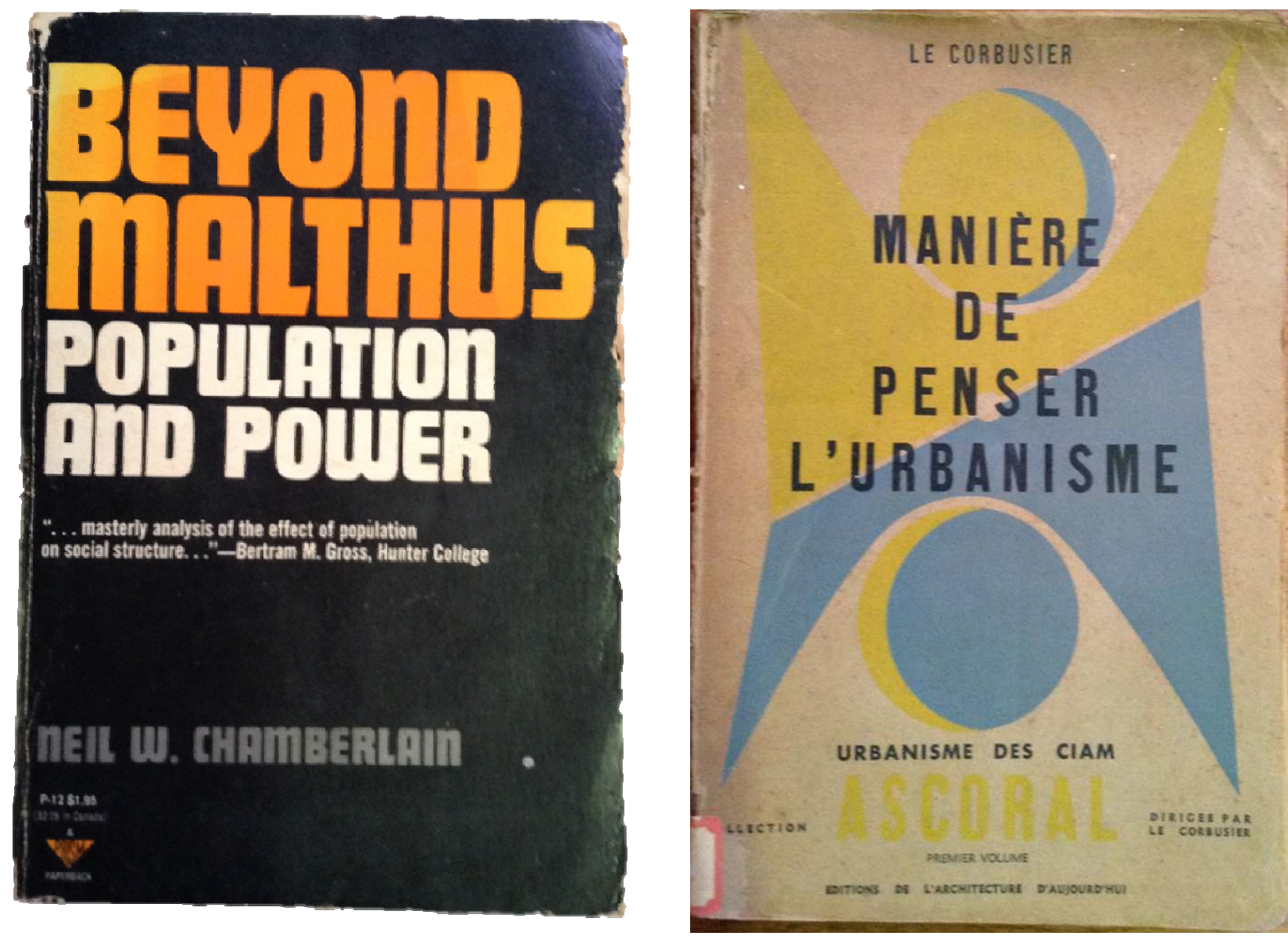

Figura 11 e 12: Exemplares da biblioteca citados no trabalho "Índices Característicos do Desenvolvimento Urbano". Fonte: Acervo da pesquisa

O engenheiro também se mostra convergente com as ideias propaladas pelo urbanismo modernista no Congresso Internacional de Arquitetura Moderna (CIAM), ao refletir sobre as proporções para determinadas funções na cidade. Encontramos, em sua biblioteca, o Manière de Penserl'Urbanisme (Figura 12), de Le Corbusier, editado pelo grupo francês do CIAM, Ascoral, com assinatura de posse que não é sua, mas com código de localização de sua biblioteca. Encontramos, ainda, o Concerning Town Planning, de 1948, versão em inglês do Propos d'Urbanisme, de 1946, com selo da livraria Kosmos, de São Paulo, e com data de aquisição de 1951, além de diversos livros de arquitetura de André Luçat.

Baltar declara, ainda no livro 'Índices Característicos $(\ldots)^{\prime}$ ', suas filiações ao urbanismo americano, quando trata da importância do texto de Harland Bartholomew "Usos do território urbano nas cidades americanas", presente em sua biblioteca, com data de aquisição de 1956 e selo da livraria Pioneira.

A "Teoria dos Índices Urbanísticos" passou a ser tônica do engenheiro, inclusive embasando as aulas de Urbanismo na Universidade do Recife, ministradas 
por ele. Em outubro de 1955, Baltar ministrou um curso de Introdução ao Planejamento Urbano na Escola e Belas Artes da Universidade da Bahia, que resultou num livro publicado em 1957, com o título "Seis Conferências de Introdução ao Planejamento Urbano".

Este livro é constituído de seis capítulos cada um relativo a uma conferência, consistindo numa síntese de suas ideias e experiências até então. A primeira, "História, geografia, economia e sociologia do fato urbano", mostra em quais campos disciplinares Baltar se referencia e a erudição necessária aos que elaboravam teorizações da e sobre a cidade.

$\mathrm{Na}$ segunda parte, o engenheiro apresenta teorias e noções em voga no campo do urbanismo, que considerava "manifestações históricas do urbanismo, e não a manifestação histórica da urbanização". Nesta parte, o autor se deteve sobre o urbanismo moderno analisando cuidadosamente a contribuição destes. Entre os autores referenciados estão Pierre Lavedan, Patrick Geddes, Ebenezer Howard e Lewis Munford ao lado dos preceitos da carta de Atenas de 1933, formando as grandes referências nesse capítulo, como também na sua obra sobre as diretrizes regionais.

A terceira conferência é mais densa e longa, onde Baltar discorre sobre seu o método científico, associando-o à teoria desenvolvida pelo padre dominicano LouisJoseph Lebret. As duas conferências seguintes ainda são dedicadas ao detalhamento desta teoria, e dispõem a concepção de urbanismo e das técnicas de conhecimento que são próprias a Baltar, mostrando adoção ao urbanismo modernista, em especial aquele propagado pelos CIAMs.

A leitura destas conferências chamam atenção pela facilidade de Baltar em articular noções e procedimentos de campos disciplinares e práticas teóricas diversas: Lavedan com Geddes, urbanismo francês com americano e inglês, modernismo corbusiano com humanismo lebretiano. Tal erudição e facilidade de transitar entre diferentes campos disciplinares são refletidas em sua biblioteca.

Durante o governo de Agamenon Magalhães foi criada a Comissão de Desenvolvimento Econômico de Pernambuco (CODEPE), com o objetivo de produzir sugestões e propostas a serem adotadas, na perspectiva da modernização do ambiente pernambucano. Entre as iniciativas desta comissão, houve a solicitação da vinda do Padre Lebret em 1954, para realização de um estudo dos impactos da industrialização que estava a acontecer no estado, incluindo apresentação sugestões para a localização de novas indústrias. O padre permaneceu quinze dias no Estado, teve como assessores diretos Antônio Baltar e Souza Barros, realizando os estudos 
segundo o método de trabalho desenvolvido originalmente por ele, característico das pesquisas de Economia e Humanismo.

Embora não tenha sido o primeiro contato, a permanência do Padre Lebret no estado pode ser considerada um importante momento na trajetória de Baltar. Textos escritos pelo engenheiro anteriores a este momento mostrem que já era de conhecimento as ideias promulgadas pelo padre e o Movimento Economia e Humanismo. 15

Baltar se mostrou bastante convergente com as ideias deste movimento surgido na França, com filiações cristãs e objetivo de propor novas formas de organização econômica, sobretudo, visando substituir a economia capitalista numa baseada nas necessidades humanas. Esta aproximação pode ser observada nos diversos escritos de Baltar que tem como uma constante a questão da promoção humana, da qualidade de vida da população e do planejamento urbano e regional. Em sua biblioteca, são inúmeras as publicações relacionadas ao tema, como por exemplo, os Cuadernos latino-americanos de Economia Humana.

O sucesso da parceria com Lebret, fez com que Baltar ingressasse em 1954 na Sociedade de Análises Gráficas e Mecanográficas Aplicadas aos Complexos Sociais (Sagmacs), que funcionava como uma cooperativa de prestação de serviços, contratada pelo serviço público e privado para realização de estudos, pesquisas e consultorias. Entre os trabalhos coordenados por Baltar, se destacam: Estrutura Urbana da Aglomeração Paulistana; Problemas de Desenvolvimento: Necessidades e Possibilidades do Estado de São Paulo; Plano de Urbanização da Cidade de Ourinhos/SP; Estrutura Urbana de Belo Horizonte/MG.

O fim da Sagmacs se deu com a instauração da Ditadura Militar, que atingiu Baltar e todos os que compunham a sociedade, o escritório foi esvaziado e a maioria dos técnicos foram perseguidos, cassados e exilados.

Cabe ressaltar que, na trajetória profissional de Baltar, muitas experiências foram vivenciadas simultaneamente, outras representaram inflexões de percurso. 0 engenheiro seguiu acumulando cargos e funções diversificadas que ampliaram seu leque de atuação. Foi membro da Esquerda Democrática ${ }^{16}$ e do Partido Socialista

\footnotetext{
15 Os textos de autoria de Baltar que mostram esta convergência são: 'Por uma Economia Humana' (1949), 'Diretrizes de um Plano Regional para o Recife' (1951) e 'Universidade, Economia e Humanismo' (1953).

16 Segundo Luiz Dário da Silva (1986: p.129), a Esquerda Democrática em Pernambuco (ED/PE) foi formada, em junho de 1945, como ala esquerda da União Democrática Nacional (UDN). Em abril de 1946, transforma-se em partido político defendendo o socialismo democrático. Em 1947, passa a denominar-se Partido Socialista Brasileiro e mantém-se no lema "Socialismo e Liberdade". No dia 14 de novembro de 1946, a Esquerda Democrática de Pernambuco, já como partido autônomo, lançou seu Manifesto ao povo pernambucano.
}

URBANA, V.6, no 8, jun.2014 - Dossiê: Cidade e Habitação na América Latina - CIEC/UNICAMP 
Brasileiro ${ }^{17}$ no qual integrou a direção municipal, estadual e nacional. Foi eleito vereador duas vezes para a Câmara Municipal do Recife, uma delas de 1955 a 1958, auxiliando o segundo governo de Pelópidas Silveira ${ }^{18}$. Encontra-se, em sua biblioteca, um volume de capa dura em seu nome, agrupando diversas legislações úteis ao exercício de vereador (Figura 13).

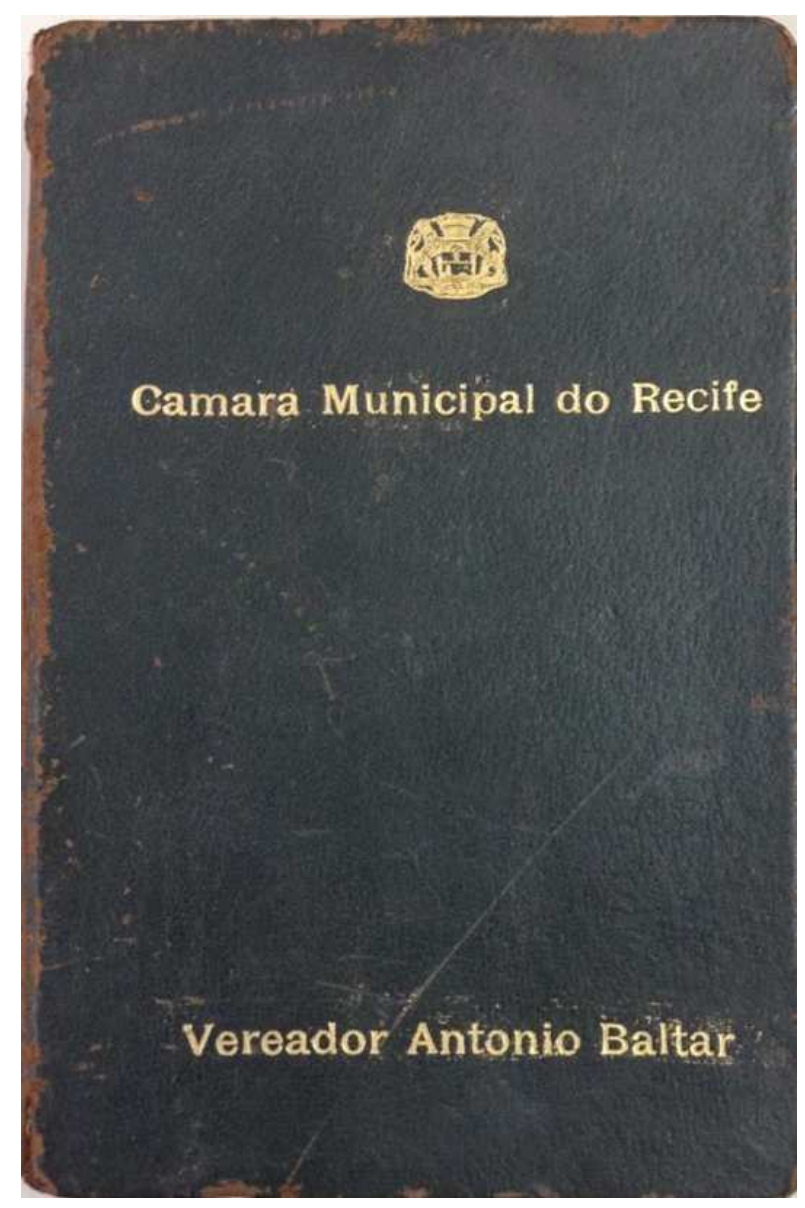

Figura 13: Volume encadernado com legislações do Recife (s/d).

Fonte: Acervo da pesquisa

Foi também eleito suplente de senador, na eleição para governo do Estado (1958-62), atuando por um curto espaço de tempo. Apesar desta trajetória política, Baltar afirmou que "(...) não tenho nenhuma vocação. Estava na política cumprindo um dever cívico" (MONTENEGRO et ali: 1995:36).

Além disso, Baltar funda o Centro de Estudos de Planejamento Urbano e Regional (Cepur), em 1962, como uma unidade técnica da Universidade do Recife.

\footnotetext{
${ }_{17}$ Ainda segundo Luiz Dário da Silva (1986: p. 122), no dia 31 de agosto de 1945 foi criado um Comitê Provisório para a ED/PE, cujo presidente foi Gilberto Freyre.

${ }^{18}$ Pelópidas da Silveira (nasceu no Recife em 15 de abril de 1915 e morreu em 6 de setembro de 2008) foi engenheiro, professor e um dos mais notáveis políticos de Pernambuco, tendo conjugado com virtuosismo a arte de governar e o exercício profissional. Sobre a atuação de Pelópidas como prefeito da cidade do Recife ver o livro de Virgínia Pontual, Uma cidade e dois prefeitos: narrativas do Recife das décadas de 1930 a 1950.
} 
Esse centro tinha por missão disseminar o planejamento urbano e regional como uma atividade técnica de ordenamento do espaço, prioritariamente das cidades pequenas e médias do Nordeste. Este centro era composto por arquitetos e urbanistas, que em grande maioria eram, também, professores da Universidade do Recife; além de aceitar em seu quadro funcional alunos de engenharia e arquitetura.

Baltar permaneceu coordenador do Cepur, entre 1963 e 1965, dado que o Golpe Militar de 1964 o afastou por meio de aposentadoria. Neste período, coordenou cinco estudos em cidades do Estado de Pernambuco e do Nordeste, mediante contratos com prefeituras e outras instituições, quais sejam: o Plano Diretor da Cidade de Petrolina, o Estudo Habitacional da Cidade de Camocim de São Félix, o Estudo Habitacional na área da Estação Experimental Barra do Bebedouro, no perímetro irrigado de Petrolina, o Plano Diretor da Cidade de Pesqueira e o Roteiro interessando ao planejamento físico-urbano, sistemático, das cidades do Nordeste do Brasil, este último contratado pela United StatesAgency for InternationalDevelopment (Usaid)-Superintendência de Desenvolvimento do Nordeste (Sudene). Os trabalhos realizados em 1965 apenas foram iniciados sob a coordenação de Baltar, como: o Plano Diretor da Cidade de Igarassú, o Plano Diretor da Cidade de Caruaru, o Plano Diretor da Cidade de Juripiranga/PB e o Estudo Redes Comerciais ${ }^{19}$.

Não encontramos, em sua biblioteca, livros que possam ter dado subsídio ao conhecimento da realidade desses lugares. No entanto, são inúmeros os livros que tratam de técnicas de irrigação, em especial a israelense, e desenvolvimento de regiões áridas, produção de alimentos e combate à fome.

No início de 1965, Baltar se exila no Chile. Com o Golpe de 1964, ele é aposentado compulsoriamente e passa a não conseguir trabalho nem em instituições públicas e nem privadas. Assim aceitou o convite das Nações Unidas para compor a equipe da Comissão Econômica para a América Latina (Cepal) 20 no Chile, onde trabalhou como economista e realizou missões em diversos países da América Latina e dos Estados Unidos. Em sua biblioteca encontra-se edição brasileira de 1964 do livro de Raul Prebisch, economista argentino então diretor presidente da CEPAL.

Baltar projeta-se na América Latina inicialmente como membro da Sagmacs. Além de publicar artigos ${ }^{21}$, passou a integrar o Conselho Diretor dos Cuadernos

\footnotetext{
${ }^{19}$ Este estudo cobriu as seguintes cidades do Estado de Pernambuco: Agrestina, Amaragi, Camocim de São Felix, Aliança, Ipojuca, Paudalho, Sanharó, Pilar, Itapissuma, Joaquim Nabuco e Maraial.

${ }^{20}$ A Cepal foi criada em 1948 pelas Nações Unidas, tendo tido como dirigente o economista argentino Raul Prebisch. Este economista manteve relações privilegiadas com o Governo Vargas e com suas idéias formou uma vertente importante do pensamento econômico latino americano de então.

${ }^{21}$ Baltar, Antônio Bezerra. "Condições do desenvolvimento econômico da região Nordeste do Brasil". Cuadernos Latinoamericanos de Economia Humana. Publicação do Centro Latinoamericano de Economia 
Latinoamericanos de Economia Humana ${ }^{22}$, em 1961, no terceiro ano de vigência desta publicação. Como era de se esperar, encontram-se volumes desse periódico na biblioteca de Baltar, inclusive números anteriores a sua entrada, como o número 1 (Figura 14). É provável que estas redes de contato tenham favorecido a participação de Baltar em curso da Cepal, assim como o convite dirigido a este engenheiro para compor o quadro de consultores desta instituição.

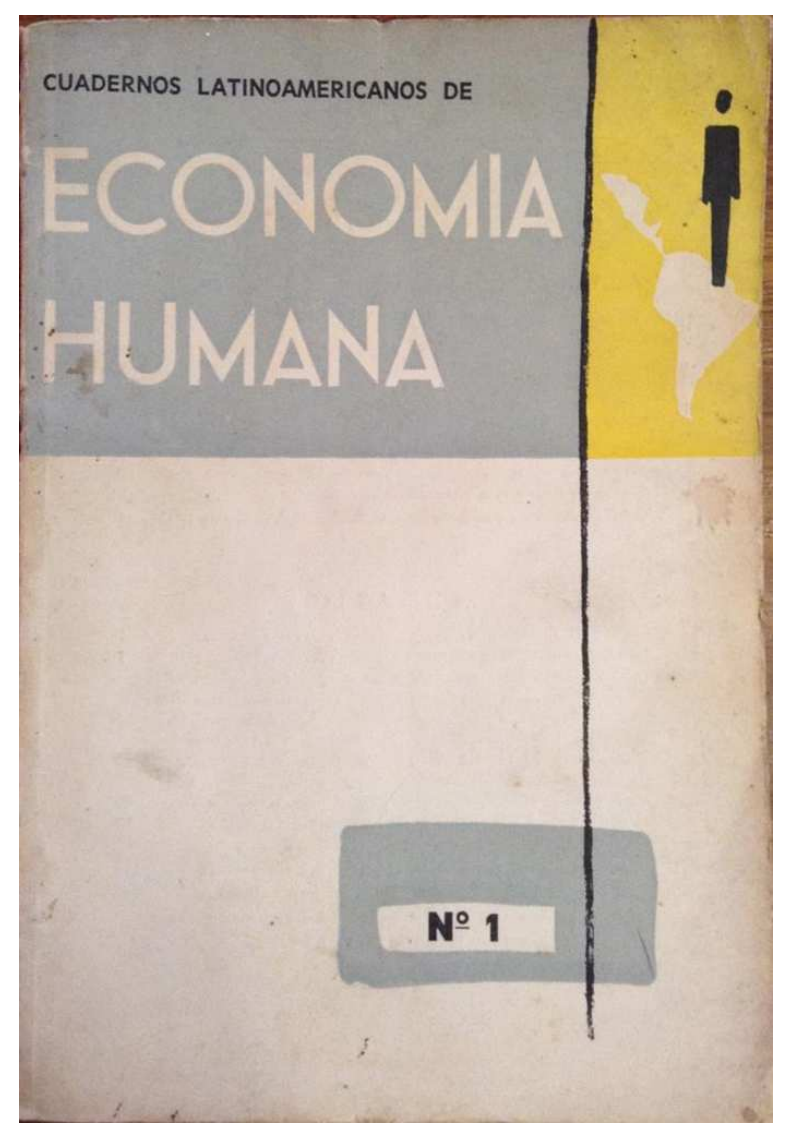

Figura 14: Exemplar no. 1 do Cuadernos latinoameriacanos de Economía Humana.

Fonte: Acervo da pesquisa.

Em 1968, Baltar prepara, como integrante da Cepal, o estudo Controle de Execução de Projetos pelo Método do Caminho Crítico, Pert (Control de La ejecución de proyectos por el Método Del Camino Crítico, Pert), temática esta presente em inúmeros livros sobre o assunto desde 1965.

\footnotetext{
Humana Montevideo, Uruguai, no 4, 1959, ano 1 (consta em nota explicativa: texto de uma conferência realizada na cidade do Recife para alunos da Escola Superior de Guerra). Ver também, Baltar, Antônio Bezerra. Notícia sobre a SUDENE: agência federal de promoção do desenvolvimento do Nordeste brasileiro. Cuadernos Latinoamericanos de Economia Humana. Publicação do Centro Latinoamericano de Economia Humana Montevideo, Uruguai, no 14, 1963, ano 6.

22 O Cuadernos Latinoamericanos de Economia Humana (CLAEH), iniciado em 1958, era uma publicação do Centro Latinoamericano de Economia Humana, sediado em Montevidéu, Uruguai e dirigido pelo arquiteto Juan Pablo Terra, membro de Economia e Humanismo.
} 
Em sua biblioteca encontra-se, ainda, caderno manuscrito de Baltar, como integrante do Instituto Latino-americanos de Pesquisas Econômicas e Sociais.

Baltar aposenta-se pela Cepal em 1977, e vai morar no Canadá, onde, segundo Macêdo (2002), ele não teria realizado nenhuma atividade remunerada. No ano de 1981, retorna finalmente ao Brasil e ensina por dois anos no Mestrado em Desenvolvimento Urbano (MDU) da UFPE. Aposenta-se definitivamente em 1983, deixando um legado à universidade que foi reconhecido no momento em que recebeu o título de professor emérito, em 1990.

Por volta de 1970, Baltar começa a adquirir livros de informática e ensino de computação, o que confirmaria um instinto renovador do engenheiro e desejo por formas e equipamentos que pudessem vir a auxiliar a prática do urbanismo (Figuras 15 e 16).
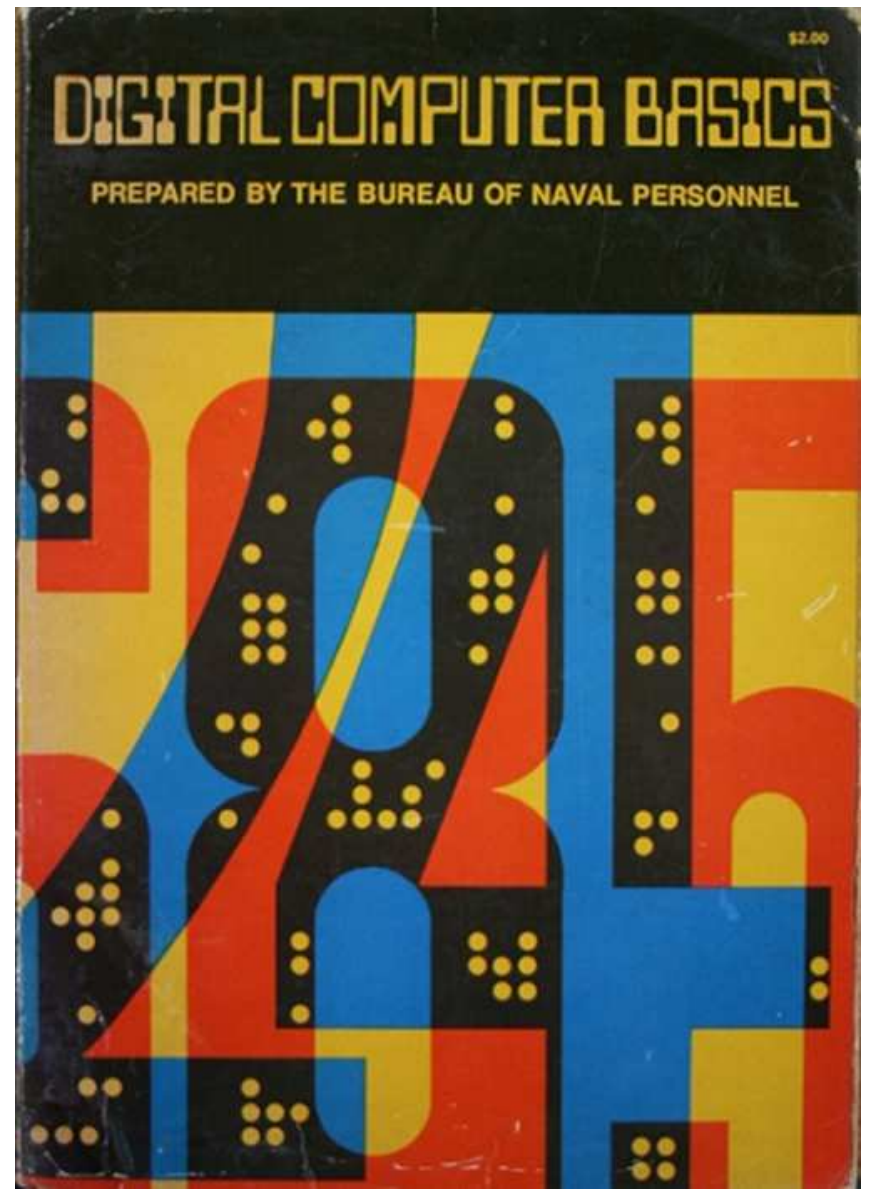

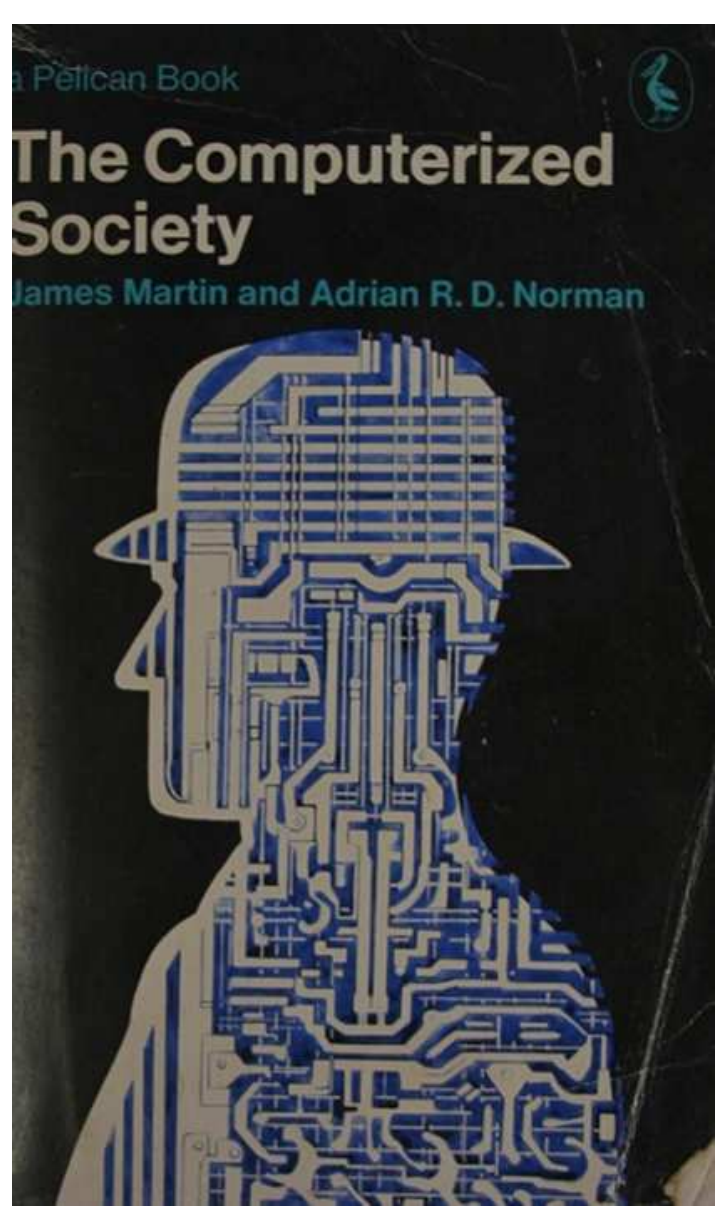

Figura 15 e 16: Livros de Informática - Digital computerbasics (1968) e The computerizedsociety (1973).

Fonte: Acervo da pesquisa.

A trajetória de uma prática que é marcada pela polivalência profissional foi traduzida por Baltar como uma "sorte de tangenciar trajetórias de pessoas que tiveram uma importância muito grande no desenvolvimento de ideias, de métodos de 
trabalho das áreas onde exerci a profissão de economista e engenheiro". Poderíamos acrescentar à sua fala, além das pessoas, os livros.

\section{REFERÊNCIAS BIBLIOGRÁFICAS}

BALTAR, Antônio Bezerra. Índices Característicos do Desenvolvimento Urbano: tentativa de sistematização de uma teoria da urbanização das unidades residenciais. Separata da Revista Portuguesa "Binário", n $\square$ 14. 1959.

Antônio Bezerra. Diretrizes de um plano regional para o Recife. Tese de Concurso para provimento da cadeira de Urbanismo e Arquitetura Paisagística na Escola de Belas Artes da Universidade do Recife. Recife. 1951. , Antônio Bezerra. Seis Conferências de Introdução ao Planejamento

Urbano. Publicação da Escola de Belas Artes da Universidade da Bahia. 1957. BALTAR, Luiz. Entrevista, em $1^{\circ}$ nov. 2013, via email. GOMES, Geraldo. Antônio Bezerra Baltar, 1915-2003.Do.Co.Mo.Mo. Recife, 2003. Disponível em: <http://www.docomomo.org.br/portaretratos\%20Baltar.htm>. Acessado em: 14 de Nov. de 2008.

LAMPARELLI, Celso. LEME, Cristina. A politização do Urbanismo no Brasil: a vertente católica. ANAIS do IX Encontro Nacional da ANPUR. Rio do Janeiro. 2001. LOPEZ, Telê. Mário de Andrade leitor e escritor: uma abordagem de sua biblioteca e de sua marginália. Rio de Janeiro: Escritos (Fundação Casa de Rui Barbosa), v. 5, p. 53-76, 2013.

MONTE, Luiz Augusto D.S. O engenheiro Antônio Bezerra Baltar: dossiê de formação profissional e contribuições ao urbanismo. Recife: Relatório de Iniciação Científica, 2009.

PONTUAL, Virgínia. O Saber Urbanístico no Governo da Cidade: uma narrativa do Recife das décadas de 1930 a 1950. São Paulo. FAU/USP. Tese de Doutoramento. 1998.

, Virgínia. A cidade e o bem comum: o engenheiro Antônio Bezerra Baltar no Recife dos anos 50. IX Encontro Nacional da ANPUR.

MACÊDO, Sílvia. Antônio Bezerra Baltar. Recife: Trabalho de Graduação, UFPE, 1997.

MONTENEGRO, Antônio T. et al. Engenheiros do Tempo: memórias da Escola de Engenharia de Pernambuco. Recife: Ed. Universitária da UFPE, 1995

SANTOS, Zeny D.M.M. Arranjo e descrição do espólio de Godofredo Filho: estudo arquivístico e catálogo informatizado. Salvador: Programa de Pós-graduação em Letras e Linguística-UFBA, 1999. 